\title{
Implementasi FSM (Finite State Machine) Pada Game Surabaya Membara
}

\author{
Dhebys Suryani Hormansyah $^{1}$, Mungki Astiningrum², Farhan Azharuddin Asyraq $^{3}$ \\ Program Studi Teknik Informatika, Jurusan Teknologi Informasi, Politeknik Negeri Malang \\ dhebys.suryani@gmail.com ${ }^{1}$, mungki_astiningrum@polinema.ac.id ${ }^{2}$, farhanasyraq@gmail.com ${ }^{3}$
}

\begin{abstract}
Abstrak
Seiring dengan perkembangan zaman, kini ilmu teknologi semakin berkembang dengan pesat. Salah satunya adalah game. Game edukasi dibuat dengan tujuan sebagai media pembelajaran alternatif. Di era digital ini, siswa sekolah cenderung lebih suka memainkan game. Hal tersebut terjadi karena semakin mudahnya untuk mendapatkan fasilitas di era digital ini. Berbagai game edukasi juga mulai muncul seiring dengan perkembangannya teknologi. Kemudian muncul berbagai macam genre dalam game yang ada. Contohnya adalah action game yang dapat diimplementasikan untuk sebuah metode pembelajaran bagi anak Sekolah Menengah Pertama (SMP). Karena pada jenjang pendidikan Sekolah Menengah Pertama (SMP) kelas IX diajarkan materi mengenai sejarah Pertempuran Surabaya. Game yang dibuat bertujuan sebagai media pembelajaran mengenai peristiwa Pertempuran Surabaya dalam bentuk visual yang menarik bagi siswa Sekolah Menengah Pertama (SMP) dan untuk mengenang peristiwa heroik di Surabaya, tanggal 10 November 1945 yang kemudian diperingati sebagai Hari Pahlawan. Kemudian dibuatlah game Surabaya

Membara. Game tersebut merupakan sebuah game 2D yang berbasis android. Game tersebut mengangkat tema tentang pejuang Surabaya melawan tentara Sekutu yang menguasai wilayah Surabaya pada tanggal 27 Oktober sampai 20 November 1945. Pada aplikasi ini akan diimplementasikan kecerdasan buatan dengan menggunakan metode Finite State Machine (FSM). Metode tersebut akan mengatur perilaku objek saat terjadi perubahan keadaan atau kondisi permainan. Aplikasi ini dibangun sebagai media pembelajaran alternatif bagi siswa kelas IX Sekolah Menengah Pertama (SMP).
\end{abstract}

Kata kunci — Game; Game Edukasi; Finite State Machine.

\section{Pendahuluan}

Game merupakan sebuah sarana hiburan yang digemari oleh masyarakat. Dari usia anak-anak, dewasa hingga tua. Selain digunakan untuk menghilangkan rasa penat dalam beraktivitas, game juga berfungsi untuk melatih pola pikir seseorang dalam mencari solusi untuk memecahkan suatu masalah yang ada dalam sebuah game. Game juga merupakan salah satu media pembelajaran. Game edukasi dibuat dengan tujuan sebagai media pembelajaran mengenal huruf dan angka, bentuk, warna bahkan untuk mengenal sejarah. Pada zaman dahulu game dimainkan secara tradisional. Namun seiring dengan berkembangnya teknologi, permainan tersebut dikembangkan ke dalam teknologi modern. Hal itu terjadi karena pada saat ini masyarakat sudah tersbiasa menggunakan gadget. Begitu pula yang terjadi terhadap anak-anak di zaman sekarang.

Action Game dapat diimplementasikan untuk sebuah metode pembelajaran bagi anak Sekolah Menengah Pertama (SMP). Karena pada jenjang pendidikan Sekolah Menengah Pertama (SMP) kelas IX diajarkan materi mengenai sejarah Pertempuran Surabaya. Game yang dibuat bertujuan sebagai media pembelajaran mengenai peristiwa Pertempuran Surabaya dalam bentuk visual yang menarik bagi siswa Sekolah Menengah Pertama (SMP) dan untuk mengenang peristiwa heroik di Surabaya, tanggal 10 November 1945 yang kemudian diperingati sebagai Hari Pahlawan. Pertempuran Surabaya merupakan satu rangkaian peristiwa pertempuran penting yang terjadi antara tentara Indonesia dan tentara Sekutu yang berlangsung sejak tanggal 27 Oktober sampai 20 November 1945. Pertempuran yang paling besar terjadi pada tanggal 10 November 1945 yang kemudian diperingati sebagai Hari Pahlawan. Pertempuran Surabaya menjadi simbol nasional atas perlawanan bangsa Indonesia terhadap penjajahan.

Dari permasalahan tersebut, penulis akan membangun sebuah aplikasi game edukasi dengan mengangkat tema Surabaya Membara. Sebelumnya, pernah dibuat sebuah penelitian sejenis oleh Dedy Teguh Pribadi namun ditambahkan metode AHP pada game yang dibuat. Kemudian, pada aplikasi ini akan diimplementasikan kecerdasan buatan dengan metode Finite State Machine (FSM). Metode Finite State Machine (FSM) digunakan untuk mengatur perilaku dari objek saat terjadi perubahan keadaan atau kondisi dalam permainan. Seiring dengan berkembangnya game, seseorang lebih memilih untuk memanfaatkan mobile device sebagai salah satu sarana untuk bermain game, yang mana aplikasi 
ini akan menggunakan system operasi android. Aplikasi ini dibangun sebagai sarana hiburan dan edukasi dalam mengenang Hari Pahlawan.

\section{Kajian Pustaka}

\subsection{Peristiwa Pertempuran Surabaya}

Pertempuran Surabaya merupakan satu rangkaian peristiwa pertempuran yang terjadi antara tantara Indonesia dan tantara Sekutu yang berlangsung sejak tanggal 27 Oktober sampai 20 November 1945. Pertempuran yang paling besar terjadi pada tanggal 10 November 1945.

\subsubsection{Peristiwa Perobekan Bendera Belanda di Hotel Yamato}

Pada masa aksi pengibaran bendera MerahPutih, timbul persoalan baru, yaitu bahwa kampkamp internian orang Belanda yang berada di Gubeng, Darmo, Sawahan, dan sebagainya ditinggalkan oleh orang-orang Belanda. Orang-orang Belanda yang bertahan selama tiga setengah tahun berada dalam tempat tersebut sebagai kaum internia, mereka seolah-olah seperti pemenang perang, mereka menghubungi pihak Jepang, untuk meminta kembali rumah, tokoh, perusahaan mereka, hingga ada beberapa yang meminta senjata dari pihak Jepang untuk kembali menyerang Republik yang baru disusun. Mereka merasa kuat, pada saat kapal udara Belanda yang datang dari Balikpapan menyebarkan selebaran yang berisi supaya mereka bersiap menerima kedatangan tentara sekutu dan Belanda dalam waktu dekat. Karena merasa posisi mereka sedikit aman, dibawah pimpinan Mr.Ploegman pada tanggal 19 September 1945, mereka menaiki Hotel Orange, dan mengibarkan bendera Belanda. Dengan sikap menantang dengan bertingkah laku gagah siap menjaga dan mempertahankan kibaran bendera Belanda.

Kemudaian terjadilah insiden perobekan bendera Belanda di hotel orange. Puluhan pemuda dan rakyat menerobos lingkaran orang-orang Belanda tersebut, hingga terjadi perkelahian yang sangat sengit, banyak dari mereka yang terluka dan pimpinan mereka Mr.Ploegman meninggal dunia dalam peristiwa itu. Bendera Belanda dapat diturunkan, dirobek bagian birunya, dan berkibarlah kembali Sang Merah-Putih. Aksi ini dipimpin oleh Koesnowibowo, anggota Angkatan Muda Kantor Kotamadya Surabaya.

Dengan meninggalnya Mr.Ploegman, rakyat Surabaya mulai mencium bau darah. Mereka menyadari bahwa yang menjadi lawan rakyat Indonesia saat ini ada dua, yaitu militer Jepang dan orang-orang bekas internian Belanda, mereka saling bantu membantu, Jepang pun mulai menyerahkan senjatanya kepada pihak Belanda.

\subsubsection{Peristiwa Terbunuhnya Jenderal A.W.S Mallaby}

Ketika rombongan Kontak Biro sampai di Gedung Internatio dicegat oleh sekelompok pemuda. Sekelompok pemuda mengajukan tuntutan mereka menyatakan selama pasukan Sekutu (Inggris) menduduki gedung tersebut, keselamatan rakyat disekitar gedung tersebut akan tetap terancam. Hal ini terbukti dengan sudah berulang kali pihak Sekutu (Inggris) menembaki rakyat secara membabi buta.

Untuk meredakan suasana, pihak Inggris mengajukan usul, Brigadir Jendral Mallaby dengan stafnya bersedia masuk ke dalam Gedung Internatio untuk menerangkan kepada pasukannya agar tidak menembaki rakyat yang berjalan disekitar gedung itu. Pihak Indonesia tidak dapat menerima usulan itu sekalipun pada mulanya tampak simpatik. Apabila usulan tersebut diterima, akan timbul situasi lain di luar gedung yang merupakan ancaman keselamatan bagi anggota Kontak Biro pihak Indonesia. Keberadaan Brigadir Jendral Mallaby bersama-sama anggota Indonesia di luar gedung akan merupakan semacam rem bagi pasukan Sekutu (Inggris) untuk menembaki pihak Indonesia, karena itu pihak Indonesia memerlukan Jendral Mallaby sebagai jaminan.

Secara tiba-tiba tentara Sekutu (Inggris) yang berada di dalam gedung menembaki kearah rakyat dan pemuda yang tersebar dilapangan Segitiga yang di depan Gedung Internatio serta kepada mobilmobil Kontak Biro. Tembakan tentara Sekutu (Inggris) lalu dibalas oleh para pemuda yang berada diluar gedung. Serangan yang tidak terduga tersebut telah menimbulkan korban yang begitu banyak dikalangan massa pemuda yang berada sekitar Gedung Internatio. Tiba- tiba mobil yang dinaiki oleh Brigadir Jendral Mallaby kena tembakan kemudian meledak dan terbakar. Tidak diketahui siapa yang menembaki mobil tersebut apakah dari pihak Sekutu (Inggris) sendiri atau dari pihak Indonesia. Dalam peristiwa itu pimpinan tentara Inggris Brigadir Jendral Mallaby tewas.

\subsubsection{Peristiwa 10 November di Surabaya}

Tanggal 10 November 1945 jam 06.00 kapalkapal perang dari the 5th Cruiser Squadron yang dipimpin oleh Real Admiral W. R. Petterson yang berada di atas kapal penjelajah HMS Sussex sebagai kapal yang berbendera Inggris yang berlabuh di depan pantai Surabaya mulai menembakkan meriamnya secara serempak ke tengah kota Surabaya. Jenderal Mansergh sudah menepati janjinya, ultimatumnya sudah berlaku, musuh sudah mulai menyerang, sejak itu setiap orang yang bersenjata di Surabaya sudah bebas dari larangan untuk menembakkan senjatanya kearah musuh yaitu Inggris pelopor kolonialisasi Belanda.

Menjelang matahari tenggelam penembakan meriam dari laut dan darat sudah berhenti. Tetapi 
begitu alam sekeliling berubah gelap dari manamana setiap kedudukan Inggris diserang oleh massa pemuda yang tidak mengenal takut. Karena hebatnya serangan terpaksa tentara Inggris ditarik mundur ke daerah pelabuhan dengan meninggalkan korban yang cukup besar. Ditariknya tentara Inggris dari tempat-tempat yang berhasil direbutnya, karena adanya kekuatiran dikalangan pimpinan tentara Inggris akan terulang pengalaman pahit selama pertempuran tiga hari. Dengan demikian serangan musuh pada hari pertama dapat dikatakan gagal.

Kemenangan yang diperoleh arek-arek Surabaya pada hari pertama pertempuran dalam pertempuran 10 November 1945 bukan karena kemahiran siasat perang. Tetapi kemenangan itu justru di peroleh tanpa siasat perang, justru perlawanan yang tidak pernah mengenal siasat ternyata menimbulkan kepanikkan musuh yang sudah terdidik dan berpengalaman luas diberbagai medan perang, karena jenis perlawanan itu belum pernah dipelajari dalam bangku pendidikan sehingga musuh yang berilmu perang tinggi itu berhasil dihalau ke daerah pelabuhan.

\subsection{Finite State Machine (FSM)}

Finite State Machine (FSM) merupakan sebuah mesin abstrak yang berfungsi untuk mendefinisikan sekumpulan kondisi yang menentukan kapan suatu state harus berubah. Setiap state yang sedang dijalankan tersebut menentukan perilaku yang terjadi pada objek bersangkutan. Diagram state FSM digambarkan pada gambar 1 sebagai berikut, (Feisal, 2015).

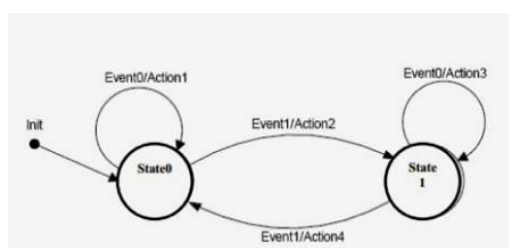

Gambar 1. Skema Finite State Machine

\subsection{Game}

Game adalah salah satu kebutuhan sekaligus menjadi masalah besar bagi para pengguna komputer, hal tersebut dikarenakan untuk dapat menjalankan suatu game dengan nyaman, maka dibutuhkan spesifikasi komputer yang relatif tinggi dibanding komputer untuk penggunaan biasa.

\subsection{Game Edukasi}

Game edukasi adalah game yang khusus dirancang untuk mengajarkan user suatu pembelajaran tertentu, pengembangan konsep dan pemahaman dan membimbing mereka dalam melatih kemampuan mereka, serta memotivasi mereka untuk memainkannya.

\subsection{Game 2D}

Game 2D adalah game yang secara matematis hanya melibatkan dua elemen koordinat kartesius yaitu $\mathrm{x}$ dan $\mathrm{y}$, sehingga konsep kamera pada game 2D hanya menentukan gambar pada game yang dapat dilihat oleh pemain.

\subsection{Kecerdasan Buatan}

Kecerdasan adalah kemampuan untuk belajar dan mengerti dari pengalaman, memahami pesan yang kontradiktif dan ambigu, menanggapi dengan cepat dan baik atas situasi yang baru, menggunakan penalaran dalam memecahkan masalah serta menyelesaikannya dengan efektif. (Suparman, 1991)

\subsection{Definisi Storyboard}

Storyboard adalah kolom teks, audio dan visualisasi dengan keterangan mengenai konten dan visualisasi yang digunakan untuk produksi sebuag course. Derajat storyboard bisa berbeda karena ada berbagai tahap yang harus dilalui sesuai tujuan pembuatan storyboard tersebut.

\subsection{Unity 3D}

Unity 3D ini digunakan sebagai media pembuatan aplikasi implementasi Finite State Machine (FSM) dari pembuatan setiap objeknya sampai penyelesaian pembuatan game. Penulis menggunakan software Unity 3D ini karena software tersebut memiliki banyak tool yang dapat digunakan untuk membuat latar dan pengoperasiannya (Roedavan, 2014).

\subsection{Adobe Illustrator}

Adobe Illustrator merupakan aplikasi untuk mengolah dan mengedit desain atau gambar vector. Aplikasi ini dikembangkan dan dipasarkan oleh Adobe Systems, Adobe Illustrator tersedia di computer, yang berarti aplikasi ini tidak bisa digunakan di perangkat lain seperti handphone, tablet dan perangkat lainnya. (Baidowi, 2015).

\subsection{Pengenalan Android}

Android adalah sebuah system operasi untuk perangkat mobile yang mencakup system operasi, middleware dan aplikasi. Android menyediakan platform terbuka bagi para pengembanguntuk menciptakan aplikasi mereka. Awalnya Google Inc. membeli Android Inc. yang merupakan pendatang baru pembuat perangkat lunak untuk ponsel dengan membentuk Open Handset Alliance (OHA). Pada saat perilisan perdana Android, 5 November 2007, Android bersama OHA menyatakan mendukung pengembangan open source.

\section{Metode Penelitian}

Dalam metode penelitian ini akan dijelaskan langkah-langkah yang dilakukan dalam merancang game Surabaya Membara sebagai berikut: 


\subsection{Studi Pustaka}

Studi pustaka ini sebagai dasar teori yang akan melandasi pengerjaan aplikasi ini dengan mencari studi pustaka yang berkaitan pada buku-buku. Sebagai bahan pertimbangan permbuatan proposal aplikasi ini.

\subsection{Pengumpulan Data}

Tahapan pengumpulan data ini dilakukan untuk memperoleh data dan informasi yang diperlukan dalam pembuatan aplikasi game ini, seperti pengumpulan asset dan materi yang akan dimasukkan dalam aplikasi.

\subsection{Perancangan Sistem}

Pada tahap perancangan sistem ini metode yang digunakan adalah Multimedia Development Life Cycle (MDLC). Metode ini terdiri dari beberapa fase yaitu konsep (concept), perancangan (design), pengumpulan bahan (material collecting), pembuatan (assembly), pengujian (testing), dan distribusi (distribution).

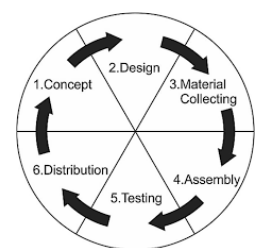

Gambar 2. Diagram Multimedia Development Life Cycle

\section{a. Konsep}

Tahapan pada proses ini meliputi pembutan konsep mengenai game akan dibuat.

\section{b. Perancangan}

Pada fase perancangan (design) dimulai dengan membuat garis besar dari tampilan dan informasi yang akan ditampilkan dilayarg. Pada tahap ini menggunakan storyboard untuk menggambarkan deskripsi tiap scene, dengan menjelaskan semua objek multimedia dan tautan pada scene yang ditampilkan. Flowchart digunakan untuk menggambarkan aliran dari satu scene ke scene lain.

\section{c. Material Collecting}

Pengumpulan bahan (material collecting) adalah tahapan dimana mengumpulkan bahan yang sesuai dengan kebutuhan yang telah direncanakan.

\section{d. Assembly}

Software merupakan kebutuhan perangkat lunak yang digunakan untuk menujang keperluan pembuatan game seperti game engine Unity, editor gambar Adobe Illustrator, Adobe Photoshop, dan editor music AudaCity. Kemudian, Dalam proses pembuatan game ini menggunakan game engine Unity. Unity merupakan aplikasi game engine yang dapat digunakan untuk membuat game 2D atau 3D. Bahasa pemrograman yang dapat digunakan di Unity adalah C\# dan javascript.

\section{e. Testing}

Pengujian (testing) pada game dilakukan dengan melakukan pengujian alpha dan betha. Pengujian alpha dilakukan setelah proses pembuatan, pengujian alpha menggunakan metode pengujian BlackBox. Metode ini dilakukan dengan menjalankan aplikasi, kemudian dilihat apakah terjadi kesalahan ketika menjalankan fungsi yang sudah teredia. Pengujian betha melibatkan pengguna akhir yaitu anak-anak atau masyarakat umum. Pada saat pengujian juga dilakukan penyebaran kuesioner mengenai aplikasi ini, kuesioner yang diberikan berisi pertanyaan yang berhubungan dengan kepuasan dan tercapainya tujuan dari pembuatan game ini.

\section{f. Distribution}

Pada tahap ini aplikasi akan disimpan pada media penyimpanan yang dapat diunduh oleh masyarakat umum. Tahap ini juga terdapat proses evaluasi terhadap produk agar dapat dikembangnkan menjadi lebih baik. Evaluasi yang didapat dapat dimasukkan untuk tahap concept pada pengembangan selanjutnya.

\section{Analisis dan Perancangan}

\subsection{Gambaran Umum Aplikasi}

Gambaran umum dari aplikasi Implementasi FSM (Finite State Machine) pada Game Suarabaya Membara meliputi,

- Aplikasi game yang dibuat bersifat single player

- Aplikasi game yang dibuat memiliki 3 level

- Aplikasi game yang dibuat memiliki 3 misi

- Aplikasi game yang dibuat berbasis Android dengan tampilan gambar 2D

- Aplikasi game yang dibuat menerapkan metode FSM (Finite State Machine)

- Aplikasi game yang dibuat dapat dimainkan oleh siswa SMP (Sekolah Menengah Pertama)

\subsection{Analisis Kebutuhan}

a. Hardware

- Sistem Operasi Mac OS Mojave

- Processor 2,5 GHz Intel Core i5

- Memory $10 \mathrm{~GB} 1600 \mathrm{MHz}$ DDR3

b. Software

- Adobe Illustrator CC 2019

- Adobe Photoshop CC 2019

- Unity 3D 2018.3.11f1 


\subsection{Perancangan Aplikasi}

a. Work Breakdown Structure (WBS)

Pada aplikasi ini menggunakan konsep dan alur dari Multimedia Development Life Cycle dan dijabarkan sesuai dengan pekerjaan yang harus dikerjakan saat pembuatan aplikasi ini. Berikut WBS yang di gambarkan pada gambar berikut ini:

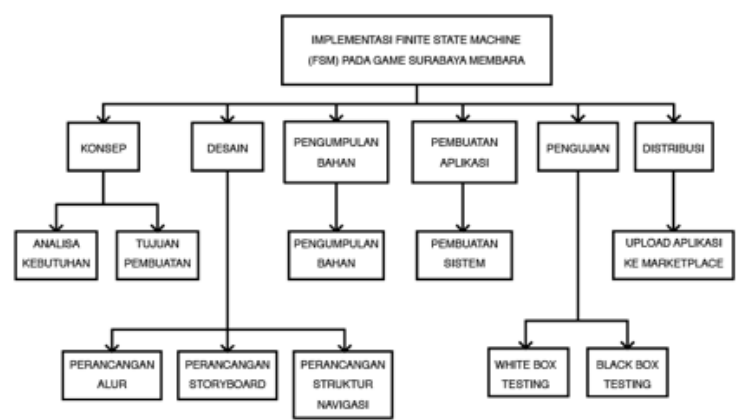

Gambar 3. Work Breakdown Structure

\section{b. Sitemap Mobile}

Sitemap Mobile merupakan salah satu cara sederhana untuk menginformasikan kepada user tentang halaman-halaman pada aplikasi.

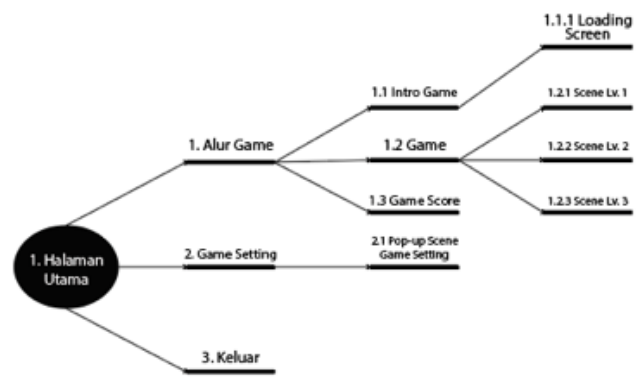

Gambar 4. Sitemap Mobile

c. Use Case Diagram

Use Case pada aplikasi berhubungan dengan interaksi user terhadap sistem. Diagram use case dilakukan oleh actor sebagai user yang menggambarkan bagaimana actor dapat menjalankan fungsi-fungsi yang terdapat pada aplikasi.

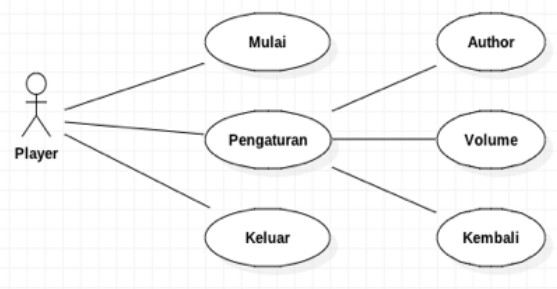

Gambar 5. Use Case Diagram

\section{d. Storyboard}

Berikut adalah alur Implementasi FSM (Finite State Machine) pada Game Surabaya Membara dalam bentuk storyboard pada table 1 ,

Tabel 1. Storyboard

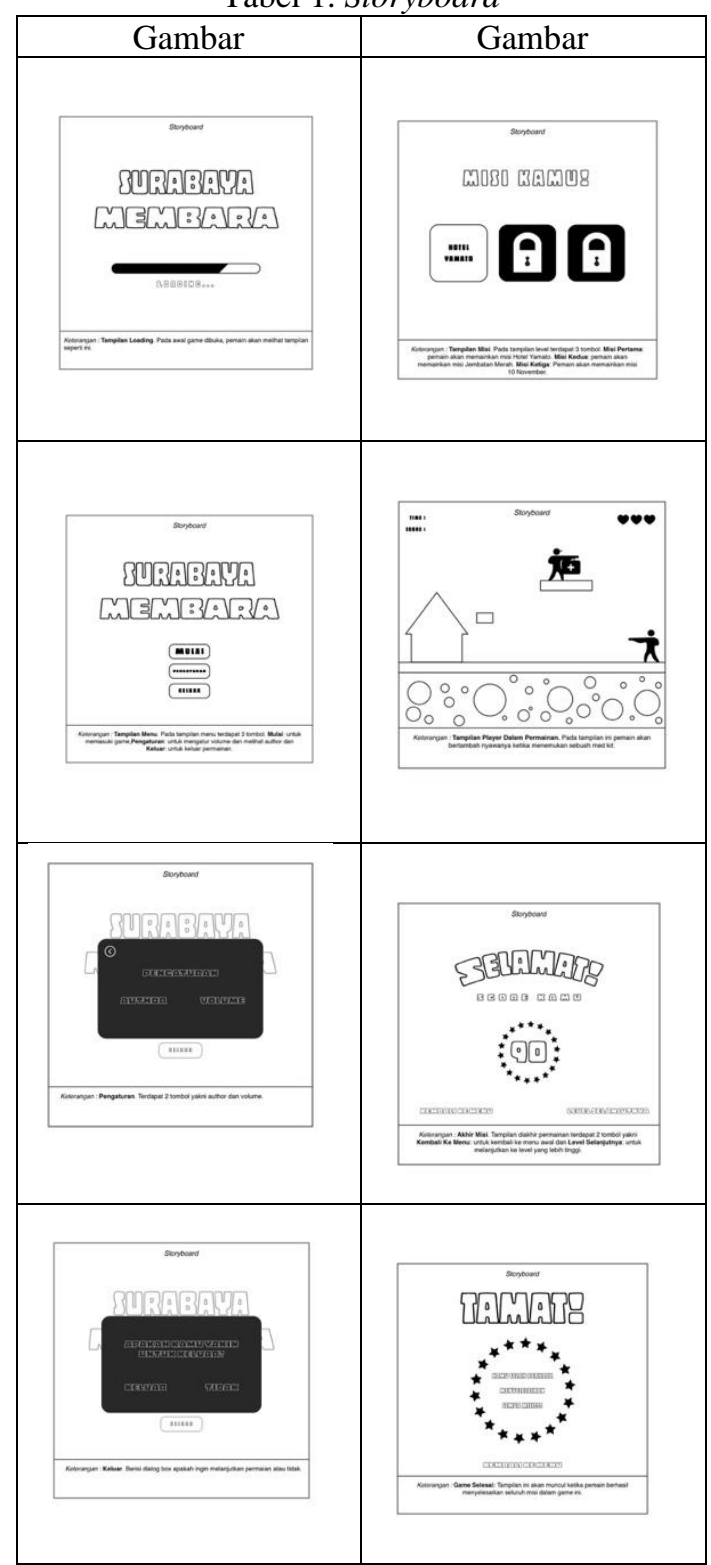

e. Penerapan Metode FSM (Finite State Machine)

Pada table 2 berikut menjelaskan rancangan alur state FSM (Finite State Machine) pada Game Surabaya Membara pada musuh shooter yang terdiri dari state (Q), event (e) dan action (a).

Tabel 2. Rancangan Alur State FSM Shooter

\begin{tabular}{|l|l|l|l|}
\hline $\begin{array}{c}\text { Current } \\
\text { State (Q) }\end{array}$ & Event (e) & Action (a) & $\begin{array}{c}\text { State } \\
\text { Transition }\end{array}$ \\
\hline Idle & $\begin{array}{l}\text { Jika jarak } \\
\text { musuh } \\
\text { dengan }\end{array}$ & $\begin{array}{l}\text { Perilaku } \\
\text { objek } \\
\text { musuh }\end{array}$ & Idle \\
\hline
\end{tabular}

$\mathrm{H}$ a 1 a $\mathrm{m}$ a $\mathrm{n} \mid \mathbf{1 5}$ 


\begin{tabular}{|c|c|c|c|}
\hline & $\begin{array}{l}\text { player } \mathrm{x} \\
<15\end{array}$ & idle & \\
\hline Idle & $\begin{array}{l}\text { Jika } \\
\text { indikator } \\
\text { jarak } \\
\text { musuh } \\
\text { dengan } \\
\text { player } \mathrm{x} \\
>15 \text { dan } \\
\mathrm{y}<8\end{array}$ & $\begin{array}{l}\text { Perilaku } \\
\text { objek } \\
\text { musuh } \\
\text { Run }\end{array}$ & Run \\
\hline Idle & $\begin{array}{l}\text { Jika jarak } \\
\text { musuh } \\
\text { dengan } \\
\text { player } \mathrm{x} \\
<8\end{array}$ & $\begin{array}{l}\text { Perilaku } \\
\text { objek } \\
\text { musuh } \\
\text { shot }\end{array}$ & Shot \\
\hline Idle & $\begin{array}{l}\text { Jika } \\
\text { nyawa } \\
\text { musuh } \\
\text { shooter }< \\
=0\end{array}$ & $\begin{array}{l}\text { Objek } \\
\text { musuh } \\
\text { death }\end{array}$ & Death \\
\hline Run & $\begin{array}{l}\text { Jika } \\
\text { nyawa } \\
\text { musuh } \\
\text { shooter }< \\
=0\end{array}$ & $\begin{array}{l}\text { Objek } \\
\text { musuh } \\
\text { death }\end{array}$ & Death \\
\hline Run & $\begin{array}{l}\text { Jika jarak } \\
\text { musuh } \\
\text { dengan } \\
\text { player } \mathrm{x} \\
<15 \text { dan } \\
\mathrm{y}>8\end{array}$ & $\begin{array}{l}\text { Perilaku } \\
\text { objek } \\
\text { musuh } \\
\text { idle }\end{array}$ & Idle \\
\hline Shot & $\begin{array}{l}\text { Jika } \\
\text { nyawa } \\
\text { musuh } \\
\text { shooter }< \\
=0\end{array}$ & $\begin{array}{l}\text { Objek } \\
\text { musuh } \\
\text { death }\end{array}$ & Death \\
\hline Shot & $\begin{array}{l}\text { Jika jarak } \\
\text { musuh } \\
\text { dengan } \\
\text { player } \mathrm{x} \\
<8\end{array}$ & $\begin{array}{l}\text { Perilaku } \\
\text { objek } \\
\text { musuh } \\
\text { idle }\end{array}$ & Idle \\
\hline
\end{tabular}

Keterangan:

- State $(\mathrm{Q})$ adalah keadaan

- Event (e) adalah kondisi

- Action (a) adalah aksi

Pada gambar 6 menerangkan transisi setiap state dari table 2 .

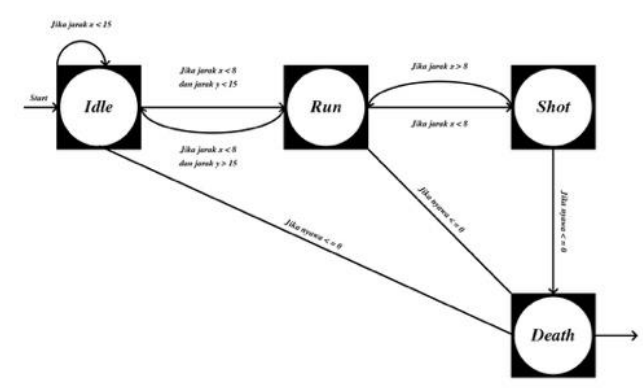

Gambar 6. Diagram State dan Transisi

Keterangan:

- (x) adalah garis horizontal

- (y) adalah garis vertical

Pada gambar 7 merupakan keterangan posisi musuh dengan player.

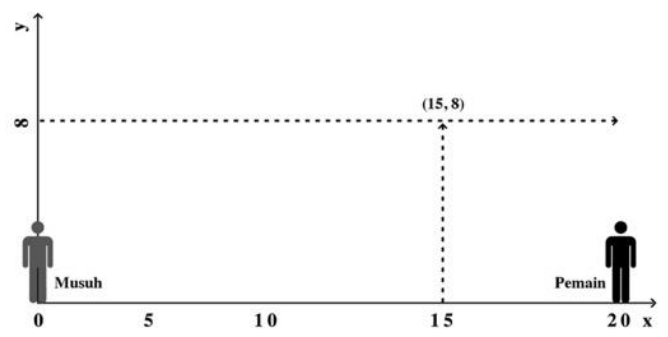

Gambar 7. Posisi Musuh dan Player

Pada table 3 berikut menjelaskan rancangan alur state FSM (Finite State Machine) pada Game Surabaya Membara pada musuh shooter yang terdiri dari state (Q), event (e) dan action (a).

Table 3. Rancangan Alur State FSM Shooter

\begin{tabular}{|l|l|l|l|}
\hline \multicolumn{1}{|c|}{$\begin{array}{c}\text { Current } \\
\text { State (Q) }\end{array}$} & Event (e) & Action (a) & $\begin{array}{c}\text { State } \\
\text { Transition }\end{array}$ \\
\hline Idle & $\begin{array}{l}\text { Jika jarak } \\
\text { musuh } \\
\text { dengan } \\
\text { player } \mathrm{x} \\
<15\end{array}$ & $\begin{array}{l}\text { Perilaku } \\
\text { objek } \\
\text { musuh idle }\end{array}$ & Idle \\
\hline Idle & $\begin{array}{l}\text { Jika } \\
\text { indikator } \\
\text { jarak } \\
\text { musuh } \\
\text { dengan } \\
\text { player } \mathrm{x} \\
>15 \text { dan } \\
\text { objek }\end{array}$ & $\begin{array}{l}\text { Pump } \\
\text { Attack }\end{array}$ & $\begin{array}{l}\text { Jump } \\
\text { Attack }\end{array}$ \\
\hline $\begin{array}{l}\text { Jump } \\
\text { Attack }\end{array}$ & $\begin{array}{l}\text { Jika jarak } \\
\text { musuh } \\
\text { dengan } \\
\text { player } \mathrm{x} \\
<15 \text { dan }\end{array}$ & $\begin{array}{l}\text { Perilaku } \\
\text { objek } \\
\text { musuh Idle }\end{array}$ & Idle \\
\hline
\end{tabular}




\begin{tabular}{|l|l|l|l|}
\hline & $\mathrm{y}>8$ & \\
\hline $\begin{array}{l}\text { Jump } \\
\text { Attack }\end{array}$ & $\begin{array}{l}\text { Jika } \\
\text { nyawa }< \\
=0\end{array}$ & $\begin{array}{l}\text { Objek } \\
\text { musuh } \\
\text { death }\end{array}$ & Death \\
\hline
\end{tabular}

\subsection{Analisis dan Perancangan}

Pembuatan asset karakter dan objek pada aplikasi menggunakan Adobe Illustrator CC 2019

a. Implementasi Objek, Karakter dan Animasi

Proses pembuatan asset desain karakter diponegoro diam, jalan, terkena serangan, shot, loncat, serang, dan mati

b. Implementasi Antar Muka

Proses pembuatan visualiasi tampilan menu utama serta beberapa scene dalam permainan.

\section{Implementasi dan Pembahasan}

\section{a. Pengujian Black Box}

Rencana pengujian akan dilakukan sistem aplikasi, pengujian dilakukan dengan teknik pengujian BlackBox. Pengujian BlackBox memfokuskan pada keperluan fungsional dari perangkat lunak.

\section{b. Pengujian Alpha}

Berdasarkan rencana pengujian, maka dapat dilakukan pengujian alpha pada permainan Surabaya Membara

\section{c. Pengujian Beta}

Pengujian beta merupakan pengujian yang dilakukan dengan tujuan untuk mengetahui bagaimana kualitas sistem yang telah dibuat. Dalam pengujian beta dilakukan terhadap responden atau calon pengguna sistem dengan menggunakan kuesioner

\section{Kesimpulan dan Saran}

Diharapkan setelah melakukan analisis, perancangan dan pengkajian maka dapat diperoleh kesimpulan sebagai berikut:

1. Diharapkan pada penelitian yang dilaksanakan pada aplikasi implementasi metode FSM (Finite State Machine) pada game perjuangan pangeran diponegoro dapat diambil keputusan bahwa penerapan metode FSM ini dapat menentukan perilaku NPC (NonCharacter Player), maka dengan ini metode FSM dapat memberikan pengaruh terhadat aksi pengguna terhadap sistem.

2. Diharapkan penelitian dapat menerapkan metode FSM pada NPC yang lebih baik lagi
3. Diharapkan penelitian dapat menambah level dan misi yang lebih beragam lagi dari sebelumnya

4. Diharapkan penelitian dapat dikembangkan dengan menambahkan metode lain

\section{Daftar Pustaka}

Abdullah, Dahlan dkk. 2016. “Game Edukasi Berbasis Role Playing Game Dengan Metode Finite State Machine (FSM)". Teknik Informatika. Universitas Malikussaleh.

Bimantoro, Tirta. dkk. $2016 . \quad$ "Pemodelan Perilaku Musuh Menggunakan Finite State Machine (FSM) Pada Game Pengenalan Unsur Kimia”. Journal of Applied Intelligent System. Vol. 1 No. 3.

Marzian, Fadel dkk. 2017. Game RPG "The Royal Sword" Berbasis Desktop Dengan Menggunakan Metode Finite Sistem (FSM). Teknik Informatika. Universitas Malikussaleh.

Marlianti, Wina. 2015. Game Edukasi "Kabayan Nyunda" Berbasis Android. Skripsi dipublikasikan. Universitas Widyatama.

Rahadian, Miftah dkk. 2016. Penerapan Metode Finite State Machine (FSM) Pada Game "The Relationship". Jurnal Informatika Mulawarman.

Setiawan, Iwan, dkk. 2015. Ilmu Pengetahuan Sosial Kelas IX. Kementerian Pendidikan dan Kebudayaan.

Dedy Teguh P. 2018. "Implementasi FSM (Finite State Machine) Pada Game Perjuangan Pangeran Diponegoro". Skripsi. Politeknik Negeri Malang.

Vilomena Theorina H.B. 2007. "Pertempuran 10 November 1945 Di Surabaya". Skripsi Universitas Sanata Dharma Yogyakarta.

Mochammad Ilham. 2015. "Historiografi Peran Laskar Hizbullah Pada Pertempuran 10 November 1945 Di Surabaya". Skripsi Universitas Islam Negeri Sunan Ampel Surabaya. 